\title{
Improvement of Cycle Capability of Fe-Substituted Li2S-Based Positive Electrode Materials by Doping with Lithium lodide
}

\section{AUTHOR(S):}

Takeuchi, Tomonari; Kageyama, Hiroyuki; Nakanishi, Koji; Kiuchi, Hisao; Katayama, Misaki; Inada, Yasuhiro; Ohta, Toshiaki; ... Sakaebe, Hikari; Kobayashi, Hironori; Matsubara, Eiichiro

\section{CITATION:}

Takeuchi, Tomonari ...[et al]. Improvement of Cycle Capability of Fe-Substituted Li2SBased Positive Electrode Materials by Doping with Lithium lodide. Journal of The Electrochemical Society 2018, 166(3): A5231-A5236

\section{ISSUE DATE:}

2018-12-27

URL:

http://hdl.handle.net/2433/241730

\section{RIGHT:}

(c) The Author(s) 2018. Published by ECS. This is an open access article distributed under the terms of the Creative Commons Attribution 4.0 License (CC BY, http://creativecommons.org/licenses/by/4.0/), which permits unrestricted reuse of the work in any medium, provided the original work is properly cited. 


\title{
Improvement of Cycle Capability of Fe-Substituted $\mathrm{Li}_{2} \mathrm{~S}$-Based Positive Electrode Materials by Doping with Lithium Iodide
}

\author{
Tomonari Takeuchi, @1,*,z Hiroyuki Kageyama, ${ }^{2,3}$ Koji Nakanishi, ${ }^{4}$ Hisao Kiuchi, ${ }^{2,3}$ \\ Misaki Katayama ${ }^{4}$ Yasuhiro Inada, ${ }^{4}$ Toshiaki Ohta, ${ }^{4}$ Toshiharu Fukunaga, ${ }^{2,3}$ \\ Hikari Sakaebe, ${ }^{1, *}$ Hironori Kobayashi, ${ }^{1}$ and Eiichiro Matsubara ${ }^{2,3}$ \\ ${ }^{I}$ National Institute of Advanced Industrial Science and Technology (AIST), Ikeda, Osaka 563-8577, Japan \\ ${ }^{2}$ Office of Society-Academia Collaboration for Innovation, Kyoto University, Gokasho, Uji, Kyoto 611-0011, Japan \\ ${ }^{3}$ Office of Society-Academia Collaboration for Innovation, Kyoto University, Yoshida, Sakyo-ku, Kyoto 606-8317, Japan \\ ${ }^{4}$ Synchrotron Radiation Center, Ritsumeikan University, Kusatsu, Shiga 525-8577, Japan
}

\begin{abstract}
For an attempt to improve the cycle capability of the $\mathrm{Li}_{8} \mathrm{FeS}_{5}$ cells, we have prepared $\mathrm{LiI}-\mathrm{doped} \mathrm{Li}_{8} \mathrm{FeS}_{5}$ composite positive electrode materials. The obtained $\mathrm{Li}_{8} \mathrm{FeS}_{5} \cdot x \mathrm{LiI}$ sample cells showed the improved cycle capability, though the initial capacity value decreased with proportional to the mass of LiI. The improved cycle performance was attributable to the suppressed resistance rise of the cells, due probably to the suppression of high-resistive surface precipitates formed by the reaction between the active material and the electrolyte. The dopant LiI would stabilize the local structure against Li extraction/insertion reactions, as well as suppress the reaction with the electrolyte, leading to the improved cycle performance.

(C) The Author(s) 2018. Published by ECS. This is an open access article distributed under the terms of the Creative Commons Attribution 4.0 License (CC BY, http://creativecommons.org/licenses/by/4.0/), which permits unrestricted reuse of the work in any medium, provided the original work is properly cited. [DOI: 10.1149/2.0361903jes]

(cc) BY
\end{abstract}

Manuscript submitted October 29, 2018; revised manuscript received December 13, 2018. Published December 27, 2018. This paper

is part of the JES Focus Issue of Selected Papers from IMLB 2018.

Lithium sulfide $\left(\mathrm{Li}_{2} \mathrm{~S}\right)$ is one of the promising cathode active materials for high-energy rechargeable lithium batteries, because it has a high theoretical capacity (ca. $1170 \mathrm{mAh} \cdot \mathrm{g}^{-1}$ ) and can be used with a variety of anode materials without lithium sources (such as graphite, silicon) in practical battery systems. ${ }^{1-15}$ However, this material shows high electrical resistivity, which gives rise to poor material utilization in the cells. In order to enhance the conductivity of $\mathrm{Li}_{2} \mathrm{~S}$, several attempts, such as forming composites with metals $\left(\mathrm{Li}_{2} \mathrm{~S}-\mathrm{Fe}, \mathrm{Li}_{2} \mathrm{~S}-\mathrm{Cu}\right)^{1-3}$ or carbon $\left(\mathrm{Li}_{2} \mathrm{~S}-\mathrm{C}\right),{ }^{4-9}$ have been performed. Recently, we have prepared $\mathrm{Li}_{2} \mathrm{~S}-\mathrm{FeS}_{x}(x=1,2)$ composites using a combination of thermal heating (spark plasma sintering; SPS) and mechanical milling. ${ }^{12,14}$ The composite samples consisted of Fe-containing low-crystalline $\mathrm{Li}_{2} \mathrm{~S}$ and showed relatively high specific capacity particularly in the case of the $\mathrm{Li}_{2} \mathrm{~S}$-rich composition, typically ca. $730 \mathrm{mAh} \cdot \mathrm{g}^{-1}$ for the $4 \mathrm{Li}_{2} \mathrm{~S} \cdot \mathrm{FeS}$ composite $\left(\mathrm{Li}_{8} \mathrm{FeS}_{5}\right)$ cell. Although relatively high initial discharge capacity was attained, the $\mathrm{Li}_{8} \mathrm{FeS}_{5}$ sample cell showed rapid capacity degradation with cycling; the capacity retention after 30 cycles was ca. $36 \%$ of the initial value.

In traditional $\mathrm{Li}-\mathrm{S}$ batteries, there still suffers from a rapid capacity fading with cycling, which are mainly related to the shuttle effect of polysulfides and the insulating nature of sulfur as well as the reduced products of $\mathrm{Li}_{2} \mathrm{~S}$ and/or $\mathrm{Li}_{2} \mathrm{~S}_{2} .{ }^{16,17}$ Since both the ionic and electronic channels are important to ensure superior cyclic stability of Li-S batteries, developing sulfur-based cathode materials with high ionic and electronic conductivity might be one of the effective ways to improve their electrochemical performances. ${ }^{17}$ Recently, Hakari et al. applied $\mathrm{Li}_{2} \mathrm{~S}$-LiX $(\mathrm{X}=\mathrm{Cl}, \mathrm{Br}$, and $\mathrm{I})$ solid solutions, showing higher ionic conductivity $\left(10^{-6}-10^{-7} \mathrm{~S} \cdot \mathrm{cm}^{-1}\right)$ as compared to $\mathrm{Li}_{2} \mathrm{~S}$ (ca. $10^{-13}$ $\mathrm{S} \cdot \mathrm{cm}^{-1}$ ), to all-solid-state cells and found the improved utilization of the active materials with superior cycle capability. ${ }^{18}$ In particular, the $\mathrm{Li}_{2} \mathrm{~S}$-LiI sample cell exhibited nearly theoretical capacity value, due mainly to the enhanced electrochemical reaction sites. On the other hand, addition of LiI to liquid electrolyte in Li-S batteries has been reported to result in the improved capacity and cycle stability due to the formation of the "protective" layer on the surface of both electrodes; such Li-permeable layer prevented the dissolution of polysulfides on the cathode side and the reduction of polysulfides on the anode side. ${ }^{19}$

In the present work, we have prepared LiI-doped $\mathrm{Li}_{8} \mathrm{FeS}_{5}$ positive electrode materials $\left(\mathrm{Li}_{8} \mathrm{FeS}_{5}-\mathrm{LiI}\right)$ for an attempt to improve the cycle

*Electrochemical Society Member.

${ }^{\mathrm{z}}$ E-mail: takeuchi.tomonari@ aist.go.jp capability of the $\mathrm{Li}_{8} \mathrm{FeS}_{5}$ cells. We have examined the effect of LiI from the standpoint of the structural change of the active material itself, as well as the formation of some protective layer on the surface of both electrodes.

\section{Experimental}

First, a blended powder of $\mathrm{Li}_{2} \mathrm{~S}$ and $\mathrm{FeS}$ in a 4: 1 molar ratio underwent SPS process (SPS-3.20 MK-IV, Fuji Electronic Industrial, Japan) at $600^{\circ} \mathrm{C}$ for 3 min under an argon atmosphere, and the product was blended with LiI and acetylene black $(\mathrm{AB})$ powders so as to the molar ratio of $4 \mathrm{Li}_{2} \mathrm{~S} \cdot \mathrm{FeS}: \mathrm{LiI}=1: x(0 \leqq x \leqq 1)$ and weight ratio of $\left(4 \mathrm{Li}_{2} \mathrm{~S} \cdot \mathrm{FeS}+x \mathrm{LiI}\right): \mathrm{AB}=9: 1$, and then mechanically milled for $8 \mathrm{~h}$ using a pulverizer ${ }^{20}$ (Model No. MC-4A, Ito Seisakusho Ltd., Japan) at a rotation speed of $1000 \mathrm{rpm}$, to yield the $\mathrm{Li}_{8} \mathrm{FeS}_{5} \cdot x \mathrm{LiI}$ samples. Most of the procedures were carried out in an argon-filled globe box, because $\mathrm{Li}_{2} \mathrm{~S}$ and $\mathrm{Li}_{8} \mathrm{FeS}_{5} \cdot x \mathrm{LiI}$ are very sensitive to atmospheric moisture.

Phase purity of the samples was checked by X-ray diffraction (XRD) (RINT TTR-III, Rigaku, Japan) using monochromatic $\mathrm{Cu} \mathrm{K} \alpha$ radiation within a $2 \theta$ range of $10-125^{\circ}$. Before the measurements, each sample was covered with Kapton film in an argon-filled glove box, and measurements were carried out within $1 \mathrm{~h}$ to minimize reaction with atmospheric moisture. Structural refinement by X-ray Rietveld analysis was carried out using the RIETAN-2000 program. ${ }^{21}$ The local atomic structure of each sample powder was examined by taking high-energy X-ray total scattering measurements, which were carried out at BL28XU of SPring- $8 .{ }^{22}$ The incident X-ray energy was $38.0 \mathrm{keV}$, and scattering patterns measured with a Q-range from 0.3 to $17 \AA^{-1}$ were analyzed using pair distribution function (PDF) analyses. ${ }^{23-27}$ A vacuum chamber was used to avoid air scattering the sample. The measured datasets were corrected for absorption, background, and polarization effects, and were normalized to obtain the reduced pair distribution function $G(r)$, according to the procedure detailed elsewhere. ${ }^{24}$ The elemental composition of the sample was estimated by inductively coupled plasma - atomic emission spectroscopy (ICP-AES, Thermo Fisher Scientific, Inc., iCAP 6500 DUO). The valence state and local structure of I atom for the sample electrodes were examined by $\mathrm{I}_{3}$-edge $\mathrm{X}$-ray absorption fine structure (XAFS) measurements, which were carried out at BL-3 of the Synchrotron Radiation Center, Ritsumeikan University. The 
$\mathrm{Li}_{8} \mathrm{FeS}_{5} \cdot x \mathrm{LiI}$

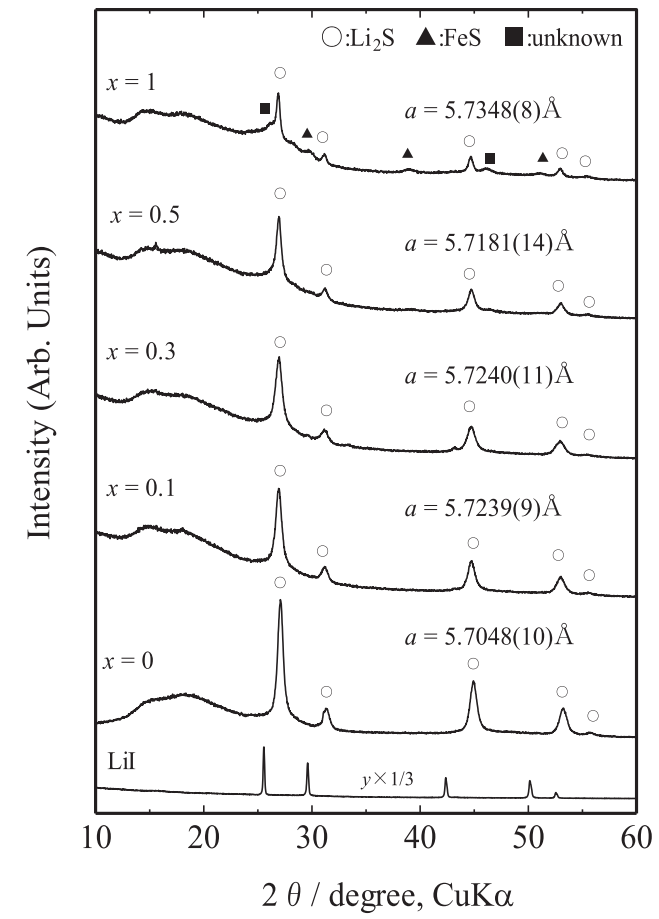

Figure 1. XRD patterns $\left(\mathrm{Cu} \mathrm{K} \alpha\right.$ radiation) for $\mathrm{Li}_{8} \mathrm{FeS}_{5} \cdot x \mathrm{LiI}$ samples with different LiI content $(x)$.

conventional transmission mode was used and the incident X-ray beam was monochromatized with a $\operatorname{Si}(220)$ crystal $(2 d=3.840 \AA) .{ }^{28,29}$ All the samples were sealed in an argon-filled aluminum-laminated bag. The surface analyses of the sample electrodes were carried out by X-ray photoelectron spectroscopy (XPS) measurements (Quantera SXM, Ulvac-PHI) using monochromatic $\mathrm{Al} \mathrm{K} \alpha_{1,2}$ radiation (1486.6 $\mathrm{eV})$. The typical analysis area was $200 \mu \mathrm{m}$ in diameter, and binding energy was calibrated with $\mathrm{C}_{1 \mathrm{~s}}$ peak $(284.6 \mathrm{eV})$.

Electrochemical lithium insertion/extraction reactions were carried out using lithium coin-type cells. The working electrode consisted of a mixture of $11.1 \mathrm{mg}$ of the $\mathrm{Li}_{8} \mathrm{FeS}_{5}$-LiI sample (containing $10 \%(1.1 \mathrm{mg}) \mathrm{AB}$ ) and $3.9 \mathrm{mg}$ of additional $\mathrm{AB}$ powder with $0.5 \mathrm{mg}$ of Teflon powder pressed into a $15 \mathrm{~mm}$ diameter tablet under a pressure of $10 \mathrm{MPa}$. The electrochemical test cell was constructed in a stainless steel coin-type configuration. The negative electrode was a $15 \mathrm{~mm}$ diameter and $0.2 \mathrm{~mm}$ thick disk of Li foil, and the separator was a microporous polyolefin sheet. A solution of $1 \mathrm{M} \mathrm{LiPF}_{6}$ in a 50:50 (by volume) mixture of ethylene carbonate (EC) and dimethylcarbonate (DMC) was used as the electrolyte. Each cell was assembled in an argon-filled glove box, and electrochemical measurements were carried out at $30^{\circ} \mathrm{C}$ initially with charging, using a TOSCAT-3100 (Toyo System) at a current density of $46.7 \mathrm{~mA} \cdot \mathrm{g}^{-1}$ (corresponding to $0.04 \mathrm{C}$ for $2 e^{-} / \mathrm{Li}_{2} \mathrm{~S}$ ) between 2.6 and $1.0 \mathrm{~V}$. The impedance of the cells was measured using a frequency response analyzer (SI 1260, Solartron Analytical) and a potentiostat (SI 1287, Solartron Analytical), covering a frequency range of $0.1 \mathrm{~Hz}$ to $10 \mathrm{MHz}$ with an applied voltage of $10 \mathrm{mV}$.

\section{Results and Discussion}

The SPS-treated $4 \mathrm{Li}_{2} \mathrm{~S}+\mathrm{FeS}$ blended powder was grayish black in color, ${ }^{12}$ and it changed to a black powder after the addition of $\mathrm{LiI}+\mathrm{AB}$ and milled for $8 \mathrm{~h}\left(\mathrm{Li}_{8} \mathrm{FeS}_{5} \cdot x \mathrm{LiI}\right)$. Figure 1 shows the XRD patterns of the obtained $\mathrm{Li}_{8} \mathrm{FeS}_{5} \cdot x \mathrm{LiI}$ samples with different LiI content $(x)$. The $\mathrm{Li}_{8} \mathrm{FeS}_{5} \cdot x \mathrm{LiI}$ samples mainly consisted of lowcrystalline $\mathrm{Li}_{2} \mathrm{~S}$. As discussed previously, ${ }^{14}$ the $\mathrm{Li}_{8} \mathrm{FeS}_{5}$ sample $(x$

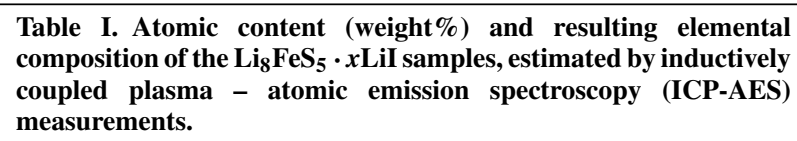

Table I. Atomic content (weight $\%$ ) and resulting elemental composition of the $\mathrm{Li}_{8} \mathrm{FeS}_{5} \cdot x \mathrm{LiI}$ samples, estimated by inductively coupled plasma - atomic emission spectroscopy (ICP-AES) measurements.

\begin{tabular}{clllll}
$x$ & $\mathrm{Li}$ & $\mathrm{Fe}$ & \multicolumn{1}{c}{$\mathrm{S}$} & $\mathrm{I}$ & composition \\
\hline 0.3 & 16 & 14.5 & 40.5 & 10 & $\mathrm{Li}_{8.9} \mathrm{FeS}_{4.9} \mathrm{I}_{0.3}$ \\
0.5 & 15 & 13.5 & 37.5 & 16 & $\mathrm{Li}_{8.9} \mathrm{FeS}_{4.8} \mathrm{I}_{0.5}$ \\
1.0 & 14.5 & 12.5 & 33 & 29 & $\mathrm{Li}_{9.3} \mathrm{FeS}_{4.6} \mathrm{I}_{1.0}$
\end{tabular}

$=0$ ) could be best described as having a $\mathrm{Li}_{2} \mathrm{~S}$-based anti-fluorite structure in which $\mathrm{Fe}$ ions partially occupy interstitial sites close to $\mathrm{Li}$ ions in the $F m \overline{3} m$ unit cell. For samples with $x \geqq 0.1$, any peaks ascribed to LiI were not detected, indicating that the added $\mathrm{Li}$ and I ions were incorporated into $\mathrm{Li}_{2} \mathrm{~S}$ lattice or LiI was present in an amorphous phase. The lattice parameters estimated from the $\mathrm{Li}_{2} \mathrm{~S}$ peaks were $a=5.7181(14)-5.7348(8) \AA$, which were larger than that of the pristine $\mathrm{Li}_{8} \mathrm{FeS}_{5}(a=5.7048(10) \AA)$. This can be explained by the partial substitution of the larger $\mathrm{I}^{-}$ions $(2.20 \AA)$ for $\mathrm{S}^{2-}$ ions $(1.84 \AA) .{ }^{30}$ Small amounts of FeS and unknown phase for $x=1$ sample $\left(\mathrm{Li}_{8} \mathrm{FeS}_{5} \cdot \mathrm{LiI}\right)$ suggest that it was beyond the solid solution limit in the $\mathrm{Li}_{8} \mathrm{FeS}_{5}$-LiI system. These results are consistent with the previous report on the $\mathrm{Li}_{2} \mathrm{~S}$-LiI solid solution, ${ }^{18}$ in which the lattice parameter increased with LiI content up to the solid solution limit of the composition $80 \mathrm{Li}_{2} \mathrm{~S} \cdot 20 \mathrm{LiI}$ (the above mentioned $\mathrm{Li}_{8} \mathrm{FeS}_{5} \cdot \mathrm{LiI}$ corresponds to $\left.83 \mathrm{Li}_{1.6} \mathrm{Fe}_{0.2} \mathrm{~S} \cdot 17 \mathrm{LiI}\right)$. The detailed atomic structure will be discussed later using PDF analyses.

Table I lists the atomic content and the resulting composition of the $\mathrm{Li}_{8} \mathrm{FeS}_{5} \cdot x$ LiI samples, estimated by ICP-AES measurements. Each sample showed similar atomic ratio to that of the starting composition; for example, the $x=0.5$ sample, initially $\mathrm{Li}_{8.5} \mathrm{FeS}_{5} \mathrm{I}_{0.5}$, was estimated to $\mathrm{Li}_{8.9} \mathrm{FeS}_{4.8} \mathrm{I}_{0.5}$. Thus, the initial atomic ratio was nearly unchanged during the present preparation process, as was in the case of $\mathrm{Li}_{8} \mathrm{FeS}_{5}{ }^{12}$

The charge and discharge curves for the $\mathrm{Li}_{8} \mathrm{FeS}_{5} \cdot x \mathrm{LiI}$ sample cells are shown in Fig. 2a. Each charge curve showed a plateau at ca. $2.5 \mathrm{~V}$, which corresponds to the oxidation of sulfur $\left(\mathrm{S}^{2-} / \mathrm{S}^{0}\right.$ or $\left.\mathrm{S}^{2-} / \mathrm{S}_{2}{ }^{2-}\right){ }^{12}$ And the subsequent discharge curve showed a longer plateau at ca. $2.0 \mathrm{~V}$, corresponding to the reduction of sulfur $\left(\mathrm{S}^{0} / \mathrm{S}^{2-}\right.$ or $\left.\mathrm{S}_{2}{ }^{2-} / \mathrm{S}^{2-}\right)$, as well as a shorter plateau at ca. $1.5 \mathrm{~V}$, corresponding to the reduction of $\mathrm{Fe}-\mathrm{S}$ components. ${ }^{12}$ Since the sample $\mathrm{Li}_{8} \mathrm{FeS}_{5}$ is a Li-deficient composition ( $\left.\left[\mathrm{Li}_{1.6} \mathrm{Fe}_{0.2}\right] \mathrm{S}\right)$, the sample cell initially showed relatively higher discharge capacity than the charge capacity; the initial $\left[\mathrm{Li}_{1.6} \mathrm{Fe}_{0.2}\right] \mathrm{S}$ changed to $\left[\mathrm{Li}_{1.8} \mathrm{Fe}_{0.2}\right] \mathrm{S}$ after the 1 st cycle by incorporating additional $\mathrm{Li}^{+}$ions supplied from anode. Remarkably, the measured capacity values decreased with the LiI content $(x)$. This is evident from the re-plotted profiles with the capacity values normalized by the mass of $\mathrm{Li}_{8} \mathrm{FeS}_{5}$, which are shown by dashed lines in Fig. 2a; each sample cell showed similar profile with comparable capacity value (ca. 750-800 $\mathrm{mAh} \cdot \mathrm{g}^{-1}$ ). These results indicate that the added LiI showed no electrochemical redox reaction contributing to the capacity value in the cell.

Contrary to the reduced capacity value, the cycle performance was much improved by the addition of LiI, Fig. 2b; particularly in the $\mathrm{Li}_{8} \mathrm{FeS}_{5} \cdot 0.5 \mathrm{LiI}$ sample cells, the capacity retention after 30 cycles was ca. $72 \%$, which was much higher than that of the pristine $\mathrm{Li}_{8} \mathrm{FeS}_{5}$ sample cells (ca. 36\%). Slight decrease in capacity retention beyond 30 cycles was attributable to the degradation of the cell components, such as electrolyte and lithium anode, due to the incomplete sealing of the present coin-type cells, as was observed also in the conventional $\mathrm{Li} / \mathrm{LiCoO}_{2}$ cells. We also carried out the same electrochemical test for the cell with the blended powder of $\mathrm{Li}_{8} \mathrm{FeS}_{5}+0.5 \mathrm{LiI}$, and found similar cycle degradation to that of the pristine $\mathrm{Li}_{8} \mathrm{FeS}_{5}$ sample cell, as shown also in Fig. 2b. Therefore, a simple blending of LiI has nearly no effect on the improvement of the cycle performance in the present $\mathrm{Li} / \mathrm{Li}_{8} \mathrm{FeS}_{5}$ cell.

Wu et al. ${ }^{19}$ reported that the addition of LiI to liquid electrolyte in Li-S batteries improved the cycle capability due to the formation of the 

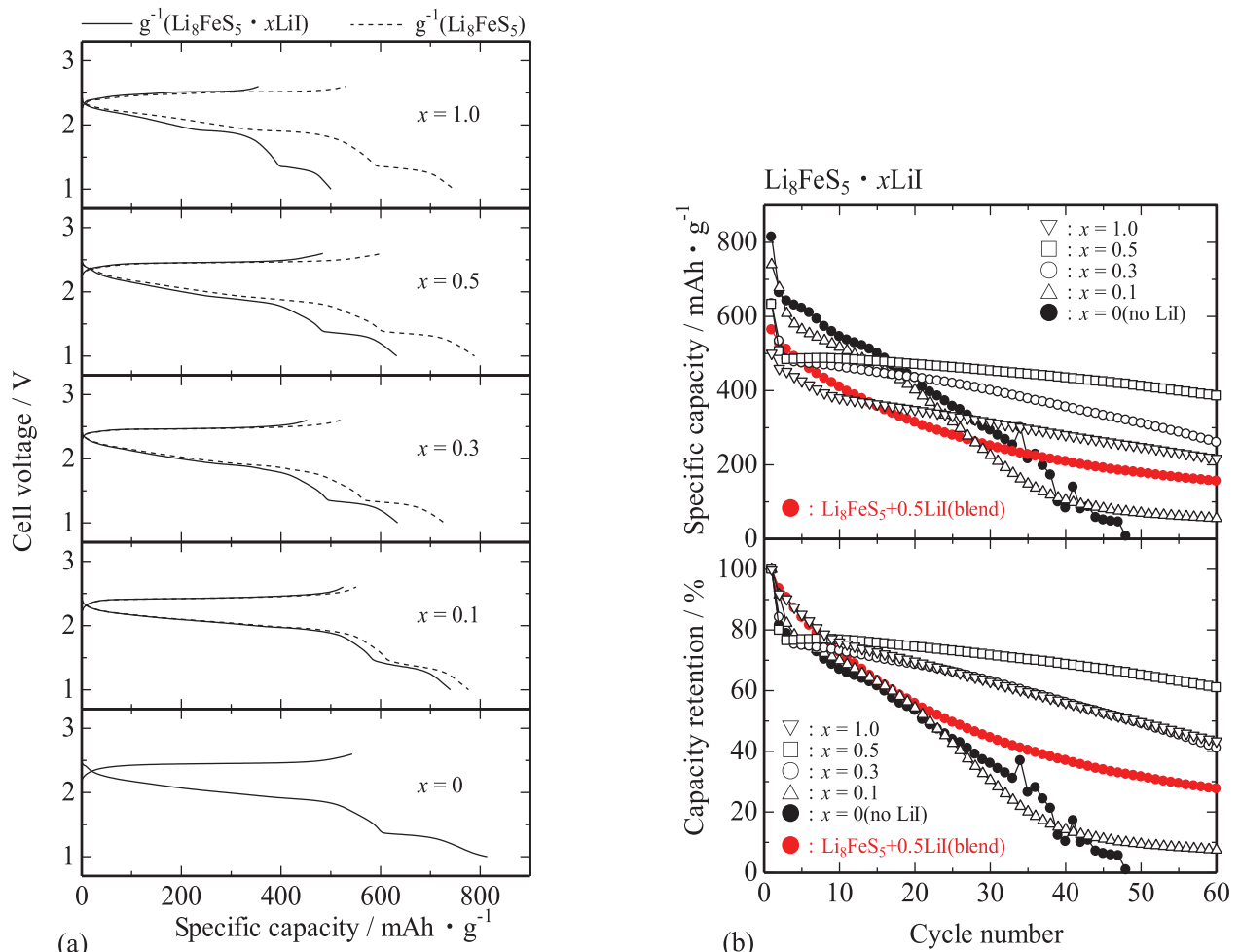

Figure 2. (a) Charge and discharge profiles for the $\mathrm{Li}_{8} \mathrm{FeS}_{5} \cdot x \mathrm{LiI}$ sample cells at $46.7 \mathrm{~mA} \cdot \mathrm{g}^{-1}$ (corresponding to $0.04 \mathrm{C}$ for $2 e^{-} / \mathrm{Li}_{2} \mathrm{~S}$ ). The solid and dashed lines represent the profiles with the capacity values normalized by the mass of $\mathrm{Li}_{8} \mathrm{FeS}_{5} \cdot x \mathrm{LiI}$ and $\mathrm{Li}_{8} \mathrm{FeS}_{5}$, respectively. (b) Cycle performances for the $\mathrm{Li}_{8} \mathrm{FeS} \mathrm{S}_{5} \cdot x \mathrm{LiI}$ sample cells at $46.7 \mathrm{~mA} \cdot \mathrm{g}^{-1}$. The capacity values are normalized by the mass of $\mathrm{Li}_{8} \mathrm{FeS}_{5} \cdot x \mathrm{LiI}$.

"protective" later on the surface of both electrodes via the reaction between the electrolyte solvent and $\mathrm{I}^{-}$radicals, and such $\mathrm{Li}$-permeable layer prevented the dissolution of polysulfides on the cathode side and the reduction of polysulfides on the anode side. In order to check similar effect in the present $\mathrm{Li} / \mathrm{Li}_{8} \mathrm{FeS}_{5} \cdot x \mathrm{LiI}$ cell, we carried out the surface analyses of both electrodes by XPS measurements. The measured XPS spectra for the $\mathrm{Li} / \mathrm{Li}_{8} \mathrm{FeS}_{5} \cdot 0.5 \mathrm{LiI}$ and $\mathrm{Li} / \mathrm{Li}_{8} \mathrm{FeS}{ }_{5}$ cells after 15 cycles showed the presence of main elements $\mathrm{Li}, \mathrm{C}, \mathrm{O}$, and $\mathrm{F}$ in both cathode and anode, suggesting the presence of some surface precipitates originated possibly from the decomposition of electrolyte, as in the case of Li-S batteries. ${ }^{19,31}$ Small amounts of sulfur $(<1$ atomic\%) were detected in both electrodes, as shown in Fig. 3 for the $\mathrm{S}_{2 \mathrm{p}}$ spectra. The cathode spectra consisted of mainly characteristic two peaks; the peak at 161-162 eV was assigned to $\mathrm{Li}-\mathrm{S}$ band, while that at $163-164 \mathrm{eV}$ to $\mathrm{S}-\mathrm{S}$ band. ${ }^{31} \mathrm{In}$ the present $\mathrm{Li} / \mathrm{Li}_{8} \mathrm{FeS}_{5} \cdot x \mathrm{LiI}$ cells, the Li-S band could be possibly originated from active materials, while the S-S band possibly from organosulfur compounds precipitated via the reaction between the active materials and electrolyte. The lower peak height of the $\mathrm{S}-\mathrm{S}$ band in the $\mathrm{Li} / \mathrm{Li}_{8} \mathrm{FeS}_{5} \cdot 0.5 \mathrm{LiI}$ cell suggests that the cathode surface was covered with less amounts of precipitates, as compared to the $\mathrm{Li} / \mathrm{Li}_{8} \mathrm{FeS}_{5}$ cell. Such precipitates would partly migrate during electrochemical cycling to deposit on the anode surface, and they were detected in the anode $S_{2 p}$ spectra, Fig. 3. Less amounts of $\mathrm{S}-\mathrm{S}$ band component in the anode of the $\mathrm{Li} / \mathrm{Li}_{8} \mathrm{FeS}{ }_{5} \cdot 0.5 \mathrm{LiI}$ cell would be originated from less amounts of S-S band component in the cathode. Since any obvious peaks ascribed to the Li-S band were not detected in the anode for both sample cells, reduction of polysulfides on the anode were hardly occurred in the $\mathrm{Li} / \mathrm{Li}_{3} \mathrm{FeS}_{5} \cdot x \mathrm{LiI}$ cells, which makes a clear contrast to the Li-S batteries. ${ }^{19,31}$ Therefore, the surface precipitates on the electrodes did not act as protective layer, but were responsible for the cycle degradation of the cells.

The above-mentioned surface precipitates on the electrodes were also suggested by the impedance measurements. Figure 4 shows the Nyquist plots for the $\mathrm{Li} / \mathrm{Li}_{8} \mathrm{FeS}_{5} \cdot 0.5 \mathrm{LiI}$ and $\mathrm{Li} / \mathrm{Li}_{8} \mathrm{FeS}_{5}$ cells after the 1 st and 20th charging. Both plots consisted of low-frequency spikes and high-frequency deformed semi-circles. According to the previous report on $\mathrm{Li}-\mathrm{S}$ cells, ${ }^{32}$ the deformed semi-circles were resolved into two semi-circles, as shown by the dashed line in Fig. 4, and the data were analyzed as being composed of the electrolyte resistance $\left(R_{\mathrm{el}}\right)$ and the charge-transfer resistance on anode $\left(R_{\mathrm{an}}\right)$ and cathode $\left(R_{\mathrm{ca}}\right)$. Each resistance showed similar value for both cells after the 1 st charging. However, it showed a significant increase after the 20th charging in the $\mathrm{Li} / \mathrm{Li}_{8} \mathrm{FeS}_{5}$ cell; particularly $R_{\text {ca }}$ value, which was a major contributor to the total resistance value, became 10 times higher. This makes a clear contrast to that of the $\mathrm{Li} / \mathrm{Li}_{8} \mathrm{FeS}_{5} \cdot 0.5 \mathrm{LiI}$

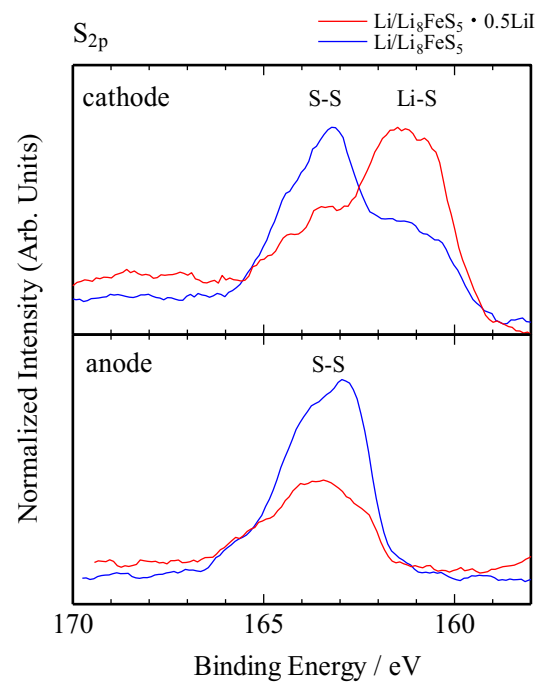

Figure 3. $\mathrm{S}_{2 \mathrm{p}}$ spectra for cathode and anode in the $\mathrm{Li} / \mathrm{Li}_{8} \mathrm{FeS}_{5} \cdot 0.5 \mathrm{LiI}$ and $\mathrm{Li} / \mathrm{Li}_{8} \mathrm{FeS} \mathrm{S}_{5}$ cells after 15 cycles. 

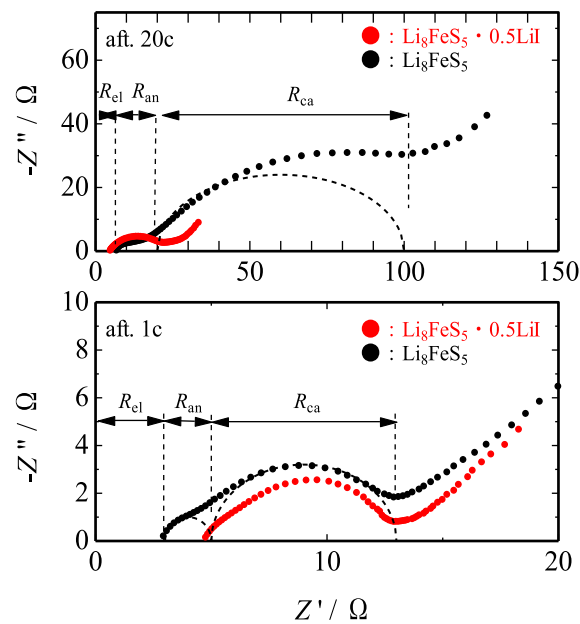

Figure 4. Nyquist plots for $\mathrm{Li} / \mathrm{Li}_{8} \mathrm{FeS}_{5} \cdot 0.5 \mathrm{LiI}$ and $\mathrm{Li} / \mathrm{Li}_{8} \mathrm{FeS}_{5}$ cells after the 1 st and 20th charging. Dashed lines represent the resolved components obtained by fitting the data to two semi-circles. The data were analyzed as being compose of the electrolyte resistance $\left(R_{\mathrm{el}}\right)$ and the charge-transfer resistances on anode $\left(R_{\mathrm{an}}\right)$ and cathode $\left(R_{\mathrm{ca}}\right)$, after the previous report on Li-S cells. ${ }^{32}$

cell, where approximately doubled resistance value was observed. The $R_{\text {ca }}$ component would be associated with the surface precipitates on the cathode, possibly consisted of high-resistive organosulfur compounds formed by the reaction between the active materials and electrolyte, and is responsible for the cycle degradation of the cells; less amounts of surface precipitates in the $\mathrm{Li} / \mathrm{Li}_{8} \mathrm{FeS}_{5} \cdot 0.5 \mathrm{LiI}$ cell showed improved cycle capability with suppressed resistance rise. Such improvement effect seemed to increase with the LiI content, but excess amount of LiI resulted in the formation of some impurity phase, as is evident in Fig. $1(x=1)$, which might inhibit the structural reversibility of $\mathrm{Li}_{8} \mathrm{FeS}_{5}$ for $\mathrm{Li}$ extraction/insertion reactions with cycling. Indeed, the capacity retention increased with the LiI content up to $x=0.5$, while it decreased beyond $x=0.5$, Fig. $2 \mathrm{~b}$. Probably these conflicting two factors were balanced around the composition at $x=0.5$ in the present $\mathrm{Li}_{8} \mathrm{FeS}_{5}-x \mathrm{LiI}$ system.

For clarifying the mechanism of suppressing the growth of surface precipitates, as well as for comprehensive understanding of the charge/discharge mechanism, we examined the structural change of the $\mathrm{Li}_{8} \mathrm{FeS}_{5} \cdot 0.5 \mathrm{LiI}$ cathode material. We disassembled the $\mathrm{Li} / \mathrm{Li}_{8} \mathrm{FeS}_{5} \cdot 0.5 \mathrm{LiI}$ cells after the charge and discharge at several steps denoted as closed circles in Fig. 5a, and carried out ex situ XRD measurements. Figure $5 \mathrm{~b}$ shows the ex situ XRD patterns of the $\mathrm{Li}_{8} \mathrm{FeS}_{5} \cdot 0.5 \mathrm{LiI}$ positive electrode during electrochemical cycling. In the 1st charge, the peaks ascribed to $\mathrm{Li}_{2} \mathrm{~S}$ decreased in its intensity and finally disappeared (sample C). There observed no definite peaks ascribed to, for example, elemental sulfur, which was anticipated to appear as the charged product in the conventional Li-S cells. In the subsequent discharge, the peaks ascribed to $\mathrm{Li}_{2} \mathrm{~S}$ appeared again (sample $\mathrm{F}$ ). In the following cycling, the $\mathrm{Li}_{2} \mathrm{~S}$ peaks repeated the disappearance/appearance regularly, indicating that the $\mathrm{Li}_{8} \mathrm{FeS}_{5} \cdot 0.5 \mathrm{LiI}$ sample shows reversible structural change for $\mathrm{Li}$ extraction/insertion reactions with maintaining the anti-fluorite structure, similarly to $\mathrm{Li}_{8} \mathrm{FeS}_{5}{ }^{12}$

To examine the local structure of the $\mathrm{Li}_{8} \mathrm{FeS}_{5} \cdot 0.5 \mathrm{LiI}$ sample in detail, we carried out PDF analysis of the high-energy X-ray total scattering data, which is particularly useful for determining the structure of amorphous or low-crystalline samples. ${ }^{23-27}$ First, we examined the local structure before electrochemical test (sample A). Figure 6a shows the experimentally obtained X-ray PDF data (reduced pair distribution function $G(r)$, which shows the probability of finding a pair of atoms, weighted by their scatter power, at distance $r$ ) for the $\mathrm{Li}_{8} \mathrm{FeS}_{5} \cdot 0.5 \mathrm{LiI}$ sample as well as those of the $\mathrm{Li}_{8} \mathrm{FeS}_{5}, \mathrm{Li}_{2} \mathrm{~S}, \mathrm{LiI}$, and $\mathrm{FeS}$ powders. As reported previously, ${ }^{14}$ the PDF of the $\mathrm{Li}_{8} \mathrm{FeS}_{5}$ sample has a similar profile to that of the $\mathrm{Li}_{2} \mathrm{~S}$ powder, and can be best explained as having a $\mathrm{Li}_{2} \mathrm{~S}$-based anti-fluorite structure in which $\mathrm{Fe}$

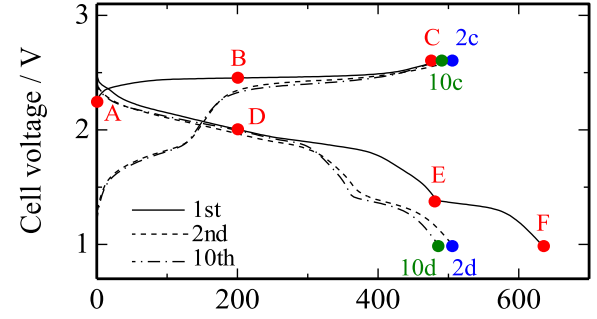

(a)

Specific capacity $/ \mathrm{mAh} \cdot \mathrm{g}^{-1}$

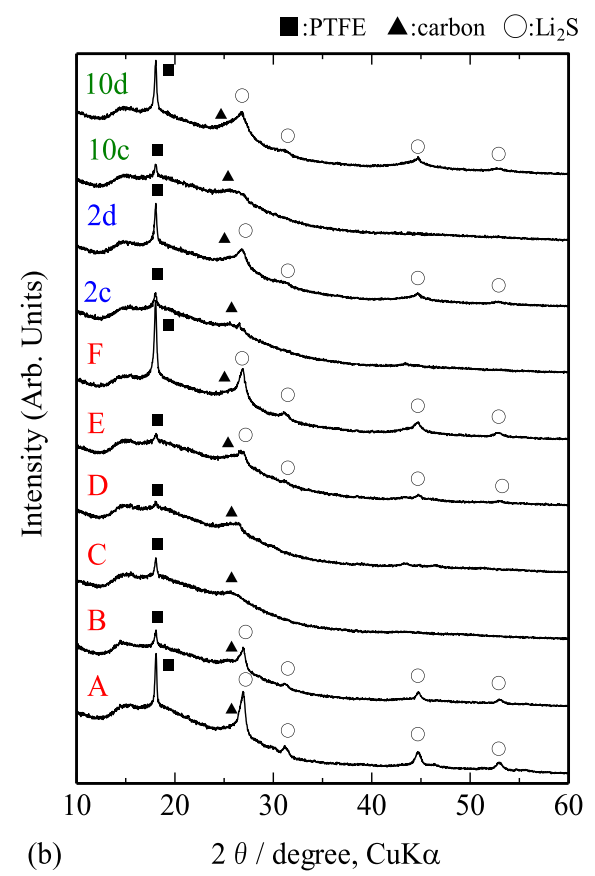

Figure 5. (a) Charge/discharge curves of the $\mathrm{Li}_{8} \mathrm{FeS}_{5} \cdot 0.5 \mathrm{LiI}$ sample cell for examining structural change. Samples provided for analyses are denoted by closed circles. (b) Ex situ XRD patterns for the $\mathrm{Li}_{8} \mathrm{FeS}_{5} \cdot 0.5 \mathrm{LiI}$ positive electrodes during electrochemical cycling.

ions partially occupy interstitial sites close to $\mathrm{Li}$ ions in the $\mathrm{Fm} \overline{3} m$ unit cell. The PDF of the $\mathrm{Li}_{8} \mathrm{FeS}_{5} \cdot 0.5 \mathrm{LiI}$ sample also has a very similar profile to that of the $\mathrm{Li}_{8} \mathrm{FeS}_{5}$ sample, indicating that the basic local structure was maintained after the addition of LiI. Since the characteristic peaks observed in the LiI powder, such as 3.01 $\AA$ for Li - I, 4.26 $\AA$ for I - I, and $5.22 \AA$ for $\mathrm{Li}$ - I, were not observed obviously, the added LiI was not present as its amorphous phase with maintaining the original crystallographic structure in the $\mathrm{Li}_{8} \mathrm{FeS}_{5} \cdot 0.5 \mathrm{LiI}$ sample.

More detailed structural analysis could be examined by XAFS measurements. Figure 7 shows the ex situ $\mathrm{I}_{2}$-edge $\mathrm{X}$-ray absorption near-edge structure (XANES) spectra for the $\mathrm{Li}_{8} \mathrm{FeS}_{5} \cdot 0.5 \mathrm{LiI}$ sample during electrochemical cycling. The spectrum before electrochemical test (sample A) was rather similar to that of $\mathrm{FeI}_{2}$, indicating that the valence state and local structure around I ions in the $\mathrm{Li}_{8} \mathrm{FeS}_{5} \cdot 0.5 \mathrm{LiI}$ sample was rather similar to those of $\mathrm{FeI}_{2}$. Possibly the I ions would occupy some interstitial sites near Fe ions in the $F m \overline{3} m$ unit cell so as to have similar local structure to that of $\mathrm{FeI}_{2}$, though the atomic position of I ions cannot be determined definitely.

The above-mentioned local structure changed irreversibly during electrochemical cycling. As shown in Fig. 6b, the PDF data changed with $\mathrm{Li}$ extraction/insertion reactions; the peak at $4.0 \AA$ attributable to $\mathrm{S}-\mathrm{S}$ interatomic distance showed splitting during charging (denoted as blue arrows), and it was not reformed to the original one in the subsequent discharging. This suggests an irreversible structural 

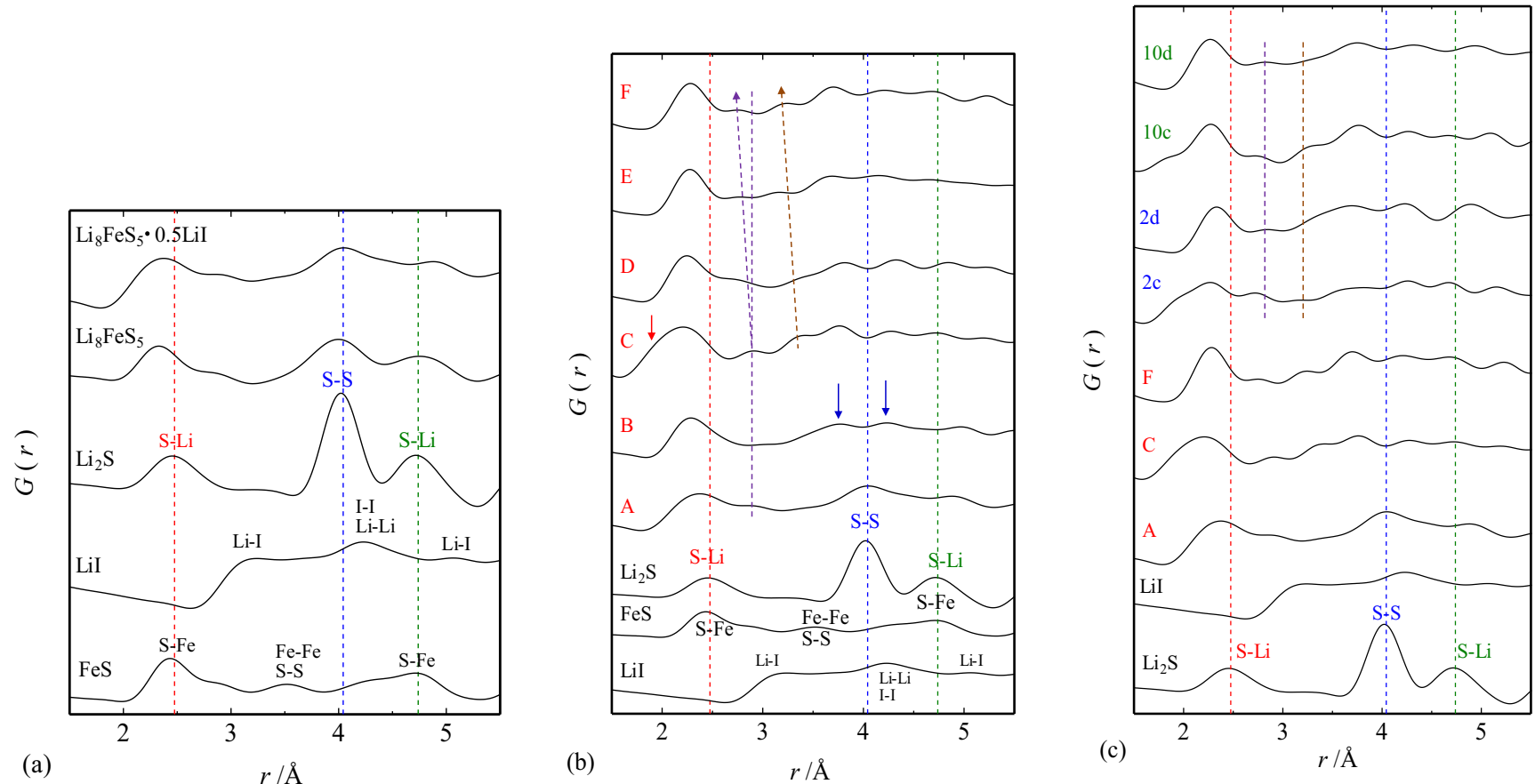

Figure 6. $\mathrm{X}$-ray radial pair distribution function (PDF) data for (a) $\mathrm{Li}_{8} \mathrm{FeS}_{5} \cdot 0.5 \mathrm{LiI}$ sample, as well as for $\mathrm{Li}_{8} \mathrm{FeS}_{5}, \mathrm{Li}_{2} \mathrm{~S}$, $\mathrm{LiI}$, and $\mathrm{FeS}$ powders, and (b) (c) those during electrochemical cycling. Sample identification is the same as denoted in Fig. 5a. The reduced pair distribution function $G(r)$ indicates the probability of finding a pair of atoms, weighted by their scatter power, at distance $r$.

change around $S$ ions, resulting in inhomogeneity with different $S$ - S distance. Such irreversible change would be responsible for the relatively large capacity loss from the 1 st to 2 nd cycle, Fig. $2 b$. In addition, shorter interatomic distance of less than $2 \AA$ appeared during charging (denoted as a red arrow), and disappeared during the subsequent discharging. This would be originated from a shorter $\mathrm{S}$ - $\mathrm{S}$ distance caused by the delithiation of $\mathrm{Li}_{8} \mathrm{FeS}_{5} \cdot 0.5 \mathrm{LiI}$, as is often observed in metal polysulfides. ${ }^{26,27}$ After the 2nd cycle, the PDF data showed rather reversible changes for Li extraction/insertion reactions, as shown in Fig. 6c, though all the peaks could not be assigned definitely. Thus, the $\mathrm{Li}_{8} \mathrm{FeS}_{5} \cdot 0.5 \mathrm{LiI}$ sample converted to delithiated phase with inhomogeneous $\mathrm{S}-\mathrm{S}$ distance during the initial charge, and then it converted to lithiated phase with still inhomogeneous $\mathrm{S}-\mathrm{S}$ distance during the subsequent discharge, and afterward they mutually repeated well-reversibly with little loss of capacity value.

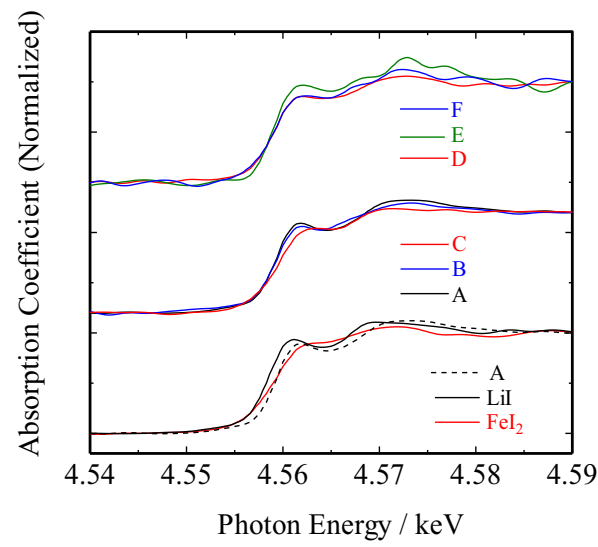

Figure 7. $\mathrm{I}_{3}$-edge $\mathrm{XANES}$ spectra for the $\mathrm{Li}_{8} \mathrm{FeS}_{5} \cdot 0.5 \mathrm{LiI}$ samples during electrochemical cycling. Sample identification is the same as denoted in Fig. 5a. $\mathrm{LiI}$ and $\mathrm{FeI}_{2}$ were used as references.
Accompanying with such structural change, the local structure around I ions also showed an irreversible change. As shown in Fig. 7 , the XAFS spectra of the $\mathrm{Li}_{8} \mathrm{FeS}_{5} \cdot 0.5 \mathrm{LiI}$ sample showed a change during the charge, and it was not recovered to the original one after the subsequent discharge. This is consistent with the results of the above PDF analyses. Hakari et al. ${ }^{18}$ reported that the $80 \mathrm{Li}_{2} \mathrm{~S} \cdot 20 \mathrm{LiI}$ solid solution may be decomposed to form $\mathrm{LiI}$ dispersed in $\mathrm{Li}_{2} \mathrm{~S}$ matrix on charge process. Similar decomposition may proceed in the $\mathrm{Li}_{8} \mathrm{FeS}_{5} \cdot 0.5 \mathrm{LiI}$ sample during the 1 st cycling; rather homogeneously distributed $\mathrm{I}^{-}$ions forming a $\mathrm{FeI}_{2}$-like local structure in the $\mathrm{Li}_{8} \mathrm{FeS}_{5} \cdot 0.5 \mathrm{LiI}$ sample were rearranged during the 1 st cycling, resulting in forming an inhomogeneous cluster dispersed in the $\mathrm{Li}_{8} \mathrm{FeS}_{5}$ matrix. Actually, the peak at $2.9 \AA$ in Fig. $6 \mathrm{~b}$, which was very close to the $\mathrm{I}-\mathrm{Fe}$ interatomic distance $(2.885 \AA)$ in $\mathrm{FeI}_{2}{ }^{33}$ and overlaps with rather shorter $\mathrm{Fe}-\mathrm{Li}(2.864 \AA)$ and $\mathrm{Li}-\mathrm{Li}(2.852 \AA)$ in $\mathrm{Li}_{8} \mathrm{FeS}_{5},{ }^{14}$ remained nearly unchanged for samples $\mathrm{A}-\mathrm{C}$ and shifted to shorter $r$-value for samples $\mathrm{D}-\mathrm{F}$ (denoted by purple dashed line). At the same time, a new peak at $3.2 \AA$ appeared in sample $\mathrm{C}$ and shifted to shorter $r$ value for samples $\mathrm{D}-\mathrm{F}$ (denoted by brown dashed line), approaching to an interatomic distance for $\mathrm{Li}$ - I in LiI (3.01 $\AA$ ). These are suggestive of the local structural change from $\mathrm{FeI}_{2}$-like to LiI-like ones during the 1st cycling. In the subsequent cycling, these characteristic two peaks remained nearly unchanged, Fig. 6c, suggesting a rather steady local structure around $\mathrm{I}^{-}$ions. Thus, the initial $\mathrm{Li}_{8} \mathrm{FeS}_{5} \cdot 0.5 \mathrm{LiI}$ converted to a delithiated one $\left(\mathrm{Li}_{y} \mathrm{FeS}_{5} \cdot 0.5 \mathrm{LiI} ; y \sim 0.2\right)$ accompanying with a structural rearrangement resulting in inhomogeneous distribution of, particularly, $\mathrm{S}$ ions, and then converted to a lithiated one $\left(\mathrm{Li}_{y} \mathrm{FeS}_{5} \cdot 0.5 \mathrm{LiI} ; y \sim 0.9\right)$ accompanying with a local structural rearrangement around, particularly, $\mathrm{I}^{-}$ions. Another notable point is that the edge positions of the XANES spectra, Fig. 7, showed little changes during the electrochemical cycling, indicating that the valence state of I ions did not change for Li extraction/insertion reactions. This result signifies that $\mathrm{I}^{-}$ions contributed little to the capacity value of the $\mathrm{Li} / \mathrm{Li}_{8} \mathrm{FeS}_{5} \cdot 0.5 \mathrm{LiI}$ cell, which is consistent with the decrease in capacity value with the LiI content, Fig. 2a. This is again indicative of rather steady state around $\mathrm{I}^{-}$ions for the Li extraction/insertion reactions, which would fasten the local structure around $\mathrm{I}^{-}$ions and 
contribute to the improvement of the structural reversibility, leading to the improved cycle capability. In addition, $\mathrm{I}^{-}$ions, which would be partly substituted for $\mathrm{S}^{2-}$ ions in the $\mathrm{Li}_{2} \mathrm{~S}$-based unit cell, would decrease the reaction points against the electrolyte, resulting in less amounts of high-resistive by-product precipitates on the cathode surface, leading to the improved cycle capability of the cell. We are now trying to simulate the structural change of the $\mathrm{Li}_{8} \mathrm{FeS}_{5} \cdot 0.5 \mathrm{LiI}$ sample during the electrochemical cycling, as well as the chemical reaction with the electrolyte, using the molecular dynamic calculations, to confirm the above-mentioned mechanism model, and the results will be reported in the near future.

\section{Conclusions}

We have successfully improved the cycle capability of $\mathrm{Fe}$ substituted $\mathrm{Li}_{2} \mathrm{~S}$-based positive electrode material $\left(\mathrm{Li}_{8} \mathrm{FeS}_{5}\right)$ by doping with LiI. The improved cycle performance was attributable to the suppressed resistance rise of the sample cells, due probably to the suppression of high-resistive surface precipitates formed by the sidereaction between the active material and the electrolyte. The dopant LiI probably stabilizes the local structure of $\mathrm{Li}_{8} \mathrm{FeS}_{5}$ against $\mathrm{Li}$ extraction/insertion reactions, as well as suppresses the side-reaction with the electrolyte, resulting in the improved cycle performance.

\section{Acknowledgment}

The synchrotron radiation experiments were performed at the BL28XU in SPring-8 with the approval of the Japan Synchrotron Radiation Research Institute (JASRI) (Proposal Nos. 2016A7601, 2016B7606, 2017A7606, 2017B7606 and 2018A7606). This work was financially supported partly by R\&D project for Li batteries (RISING2 Project) by METI and NEDO.

\section{ORCID}

Tomonari Takeuchi (D) https://orcid.org/0000-0002-5255-7316

\section{References}

1. M. N. Obrovac and J. R. Dahn, Electrochem. Solid-State Lett., 5, A70 (2002).

2. A. Hayashi, R. Ohtsubo, and M. Tatsumisago, Solid State Ionics, 179, 1702 (2008).

3. A. Hayashi, R. Ohtsubo, T. Ohtomo, F. Mizuno, and M. Tatsumisago, J. Power Sources, 183, 422 (2008).

4. M. Nagao, A. Hayashi, and M. Tatsumisago, J. Mater. Chem., 22, 10015 (2012).

5. T. Takeuchi, H. Sakaebe, H. Kageyama, H. Senoh, T. Sakai, and K. Tatsumi, J. Power Sources, 195, 2928 (2010).
6. T. Takeuchi, H. Kageyama, K. Nakanishi, M. Tabuchi, H. Sakaebe, T. Ohta, H. Senoh, T. Sakai, and K. Tatsumi, J. Electrochem. Soc., 157, A1196 (2010).

7. J. Hassoun, Y-K. Sun, and B. Scrosati, J. Power Sources, 196, 343 (2011).

8. K. Cai, M-K. Song, E. J. Cairns, and Y. Zhang, Nano Lett., 12, 6474 (2012).

9. K. Han, J. Shen, C. M. Hayner, H. Ye, M. C. Kung, and H. H. Kung, J. Power Sources, 251, 331 (2014).

10. Z. Lin, Z. Liu, N. J. Dudney, and C. Liang, ACS Nano, 7, 2829 (2013).

11. T. Takeuchi, H. Kageyama, K. Nakanishi, Y. Inada, M. Katayama, T. Ohta, H. Senoh, H. Sakaebe, T. Sakai, K. Tatsumi, and H. Kobayashi, J. Electrochem. Soc., 159, A75 (2012).

12. T. Takeuchi, H. Kageyama, K. Nakanishi, M. Ogawa, T. Ohta, A. Sakuda, H. Sakaebe, H. Kobayashi, and Z. Ogumi, J. Electrochem. Soc., 162, A1745 (2015).

13. T. Takeuchi, H. Kageyama, M. Ogawa, K. Mitsuhara, K. Nakanishi, T. Ohta, A. Sakuda, H. Kobayashi, H. Sakaebe, and Z. Ogumi, Solid State Ionics, 288, 199 (2016).

14. T. Takeuchi, H. Kageyama, N. Taguchi, K. Nakanishi, T. Kawaguchi, K. Ohara, K. Fukuda, A. Sakuda, T. Ohta, T. Fukunaga, H. Sakaebe, H. Kobayashi, and E. Matsubara, Solid State Ionics, 320, 387 (2018)

15. Y. Yang, M. T. McDowell, A. Jackson, J. J. Cha, S. S. Hong, and Y. Cui, Nano Lett., 10, $1486(2010)$

16. A. Manthiram, S. H. Chung, and C. Zu, Adv. Mater., 27, 1980 (2015).

17. H. Zhang, P. Zuo, J. Hua, Y. Ma, C. Du, X. Cheng, Y. Gao, and G. Yin, Electrochim. Acta, 238, 257 (2017).

18. T. Hakari, A. Hayashi, and M. Tatsumisago, Adv. Sustainable Syst., 1700017 (2017).

19. F. Wu, J. T. Lee, N. Nitta, H. Kim, O. Borodin, and G. Yushin, Adv. Mater., 27, 101 (2015).

20. T. Takeuchi, H. Kageyama, K. Nakanishi, T. Ohta, A. Sakuda, H. Sakaebe, H. Kobayashi, K. Tatsumi, and Z. Ogumi, ECS Electrochem. Lett., 3, A31 (2014).

21. F. Izumi and T. Ikeda, Mater. Sci. Forum, 321-324, 198 (2000).

22. H. Tanida, K. Fukuda, H. Murayama, Y. Orikasa, H. Arai, Y. Uchimoto, E. Matsubara, T. Uruga, K. Takeshita, S. Takahashi, M. Sano, H. Aoyagi, A. Watanabe, N. Nariyama, H. Ohashi, H. Yumoto, T. Koyama, Y. Senba, T. Takeuchi, Y. Furukawa, T. Ohata, T. Matsushita, Y. Ishizawa, T. Kudo, H. Kimura, H. Yamazaki, T. Tanaka, T. Bizen, T. Seike, S. Goto, H. Ohno, M. Takata, H. Kitamura, T. Ishikawa, T. Ohta, and Z. Ogumi, J. Synchrotron Radiat., 21, 268 (2014).

23. T. Proffen, S. J. L. Billinge, T. Egami, and D. Louca, Z. Krist, 218, 132 (2003).

24. S. Kohara, M. Itou, K. Suzuya, Y. Inamura, Y. Sakurai, Y. Ohishi, and M. Takata, J. Phys. Condens. Matter, 19, 506101 (2007).

25. K. Ohara, Y. Kawakita, L. Pusztai, L. Temleitner, S. Kohara, N. Inoue, and S. Takeda, J. Phys. Condens. Matter, 22, 404203 (2010).

26. A. Sakuda, K. Ohara, K. Fukuda, K. Nakanishi, T. Kawaguchi, H. Arai, Y. Uchimoto, T. Ohta, E. Matsubara, Z. Ogumi, T. Okumura, H. Kobayashi, H. Kageyama, M. Shikano, H. Sakaebe, and T. Takeuchi, J. Am. Chem. Soc., 139, 8796 (2017).

27. A. Sakuda, K. Ohara, T. Kawaguchi, K. Fukuda, K. Nakanishi, H. Arai, Y. Uchimoto, T. Ohta, E. Matsubara, Z. Ogumi, K. Kuratani, H. Kobayashi, M. Shikano, T. Takeuchi, and H. Sakaebe, Sci. Rep., 8, 15086 (2018)

28. K. Nakanishi, S. Yagi, and T. Ohta, AIP Conf. Proc., 1234, 931 (2010).

29. M. Kiguchi, T. Yokoyama, D. Matsumura, H. Kondoh, T. Ohta, and Y. Kitajima, Phys. Rev. B, 60, 16205 (1999)

30. R. D. Shannon and C. T. Prewitt, Acta Cryst., B25, 925 (1969).

31. Y. Diao, K. Xie, S. Xiong, and X. Hong, J. Power Sources, 235, 181 (2013).

32. E. Peled, I. Shekhtman, T. Mukra, M. Goor, I. Belenkaya, and D. Golodnitsky, J. Electrochem. Soc., 165, A6051 (2018).

33. ICSD (Inorganic Crystal Structure Database) code 52369. 